\title{
Estimation of Wear Resistance for Multilayer Coatings Obtained by Nitrogenchroming
}

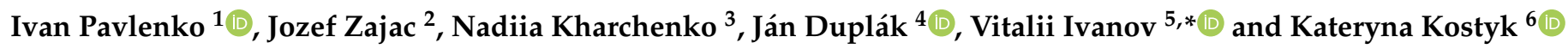 \\ 1 Department of Computational Mechanics Named after Volodymyr Martsynkovskyy, Sumy State University, \\ 40007 Sumy, Ukraine; i.pavlenko@omdm.sumdu.edu.ua \\ 2 Faculty of Manufacturing Technologies with a Seat in Prešov, Technical University of Košice, \\ 08001 Prešov, Slovakia; jozef.zajac@tuke.sk \\ 3 Department of Applied Material Science and Technology of Constructional Materials, Sumy State University, \\ 40007 Sumy, Ukraine; n.harchenko@pmtkm.sumdu.edu.ua \\ 4 Department of Automobile and Manufacturing Technologies, Technical University of Košice, \\ 08001 Prešov, Slovakia; jan.duplak@tuke.sk \\ 5 Department of Manufacturing Engineering, Machines and Tools, Sumy State University, 40007 Sumy, Ukraine \\ 6 Department of Foundry, Kharkiv Polytechnic Institute, National Technical University, 61002 Kharkiv, Ukraine; \\ Kateryna.Kostyk@khpi.edu.ua \\ * Correspondence: ivanov@tmvi.sumdu.edu.ua
}

Citation: Pavlenko, I.; Zajac, J.; Kharchenko, N.; Duplák, J.; Ivanov, V.; Kostyk, K. Estimation of Wear Resistance for Multilayer Coatings Obtained by Nitrogenchroming. Metals 2021, 11, 1153. https:// doi.org/10.3390/met11081153

Academic Editor: Belén Díaz Fernández

Received: 17 June 2021

Accepted: 19 July 2021

Published: 21 July 2021

Publisher's Note: MDPI stays neutral with regard to jurisdictional claims in published maps and institutional affiliations.
Abstract: This article deals with improving the wear resistance of multilayer coatings as a fundamental problem in metal surface treatment, strengthening elements of cutting tools, and ensuring the reliability of machine parts. It aims to evaluate the wear depth for multilayer coatings by the mass loss distribution in layers. The article's primary purpose is to develop a mathematical method for assessing the value of wear for multilayer steel-based coatings. The study material is a multilayer coating applied to steel DIN C80W1. The research was performed using up-to-date laboratory equipment. Nitrogenchroming has been realized under overpressure in two successive stages: nitriding for $36 \mathrm{~h}$ at temperature $540{ }^{\circ} \mathrm{C}$ and chromizing during $4 \mathrm{~h}$ at temperature $1050{ }^{\circ} \mathrm{C}$. The complex analysis included several options: X-ray phase analysis, local micro-X-ray spectral analysis, durometric analysis, and determination of wear resistance. These analyses showed that after nitrogenchroming, the three-layer protective coating from $\mathrm{Cr}_{23} \mathrm{C}_{6}, \mathrm{Cr}_{7} \mathrm{C}_{3}$, and $\mathrm{Cr}_{2} \mathrm{~N}$ was formed on the steel surface. Spectral analysis indicated that the maximum amount of chromium $92.2 \%$ is in the first layer from $\mathrm{Cr}_{23} \mathrm{C}_{6}$. The maximum amount of carbon $8.9 \%$ characterizes the layer from $\mathrm{Cr}_{7} \mathrm{C}_{3}$. Nitrogen is concentrated mainly in the $\mathrm{Cr}_{2} \mathrm{~N}$ layer, and its maximum amount is $9.4 \%$. Additionally, it was determined that the minimum wear is typical for steel DIN C80W1 after nitrogenchroming. The weight loss of steel samples by $25 \mathrm{mg}$ was obtained. This value differs by $3.6 \%$ from the results evaluated analytically using the developed mathematical model of wear of multilayer coatings after complex metallization of steel DIN C80W1. As a result, the impact of the loading mode on the wear intensity of steel was established. As the loading time increases, the friction coefficient of the coated samples decreases. Among the studied samples, plates from steel DIN C80W1 have the lowest friction coefficient after nitrogenchroming. Additionally, a linear dependence of the mass losses on the wearing time was obtained for carbide and nitride coatings. Finally, an increase in loading time leads to an increase in the wear intensity of steels after nitrogenchroming. The achieved scientific results are applicable in developing methods of chemical-thermal treatment, improving the wear resistance of multilayer coatings, and strengthening highly loaded machine parts and cutting tools.

Keywords: sample; counterbody; chemical-thermal treatment; layer density; mass loss distribution; wear resistance; multilayer coating

\section{Introduction}

Machining of parts is accompanied by a high wear intensity of the cutting tool's working parts. In turn, the improvement of mechanical and thermophysical properties of 
the tool material leads to an increase in the resistance of the contact surfaces of the tool to micro and macro destructions. This positive effect can be achieved by increasing the hardness, resistance to high-temperature corrosion and oxidation, decreasing the adhesion and diffusion interaction with the machined material, and reducing the thermomechanical stress during the cutting process. As a result, the wear intensity of the cutting tool is decreased, and the stability period is increased. These effects lead to an increase in production quality and a decrease in the cutting tool costs.

Improving the results of the cutting process can be implemented in several ways, mainly by changing the main parameters of the cutting process (e.g., velocity and feed) $[1,2]$ or improving the tool design [3-5]. However, the most significant positive results can be achieved using the tool and structural materials from wear-resistant coatings with high physical, mechanical and chemical properties [6,7].

Therefore, the research on obtaining wear-resistant coatings and studying their properties and characteristics are urgent scientific problems. The problem of estimation of the wear depth for multilayer coatings is also essential in chemical-thermal treatment. In multilayer surface machining, the issue of ensuring wear resistance is also valuable. Additionally, ensuring the reliability of highly loaded units of machines (e.g., shafts, bearing supports, bushing parts, and couplings) by strengthening metal parts is also an urgent problem.

Numerous studies in materials science highlight the current state of the studied problem of ensuring wear resistance of multilayer coatings. Notably, Storozhenko et al. [8] studied the structure and wear resistance of multilayer coatings. Svirzhevskyi et al. [9] developed a method for evaluating the wear resistance of the contact surfaces for rolling bearings. Al-Rekaby et al. [10] proposed the optimal choice of parameters for the chemicalthermal treatment of steels. Hovorun et al. [11] developed wear-resistant alloys in an abrasive environment. Pogrenjak et al. [12] studied phase composition, thermal stability, and mechanical properties of superhard nanocomposite coatings.

Additionally, Murčinková et al. [13] analyzed stress distribution in multilayer coatings of tools. Lehocka et al. [14] compared wear resistance efficiency on surface treatment of metals. Kharlamov et al. [15] studied the influence of different factors on the properties of carbide coatings. Kulesh et al. [16] studied the structure, morphology, and mechanical properties of boron-carbon coatings. Tarelnyk et al. [17] improved the electrospark deposition method for obtaining multilayer coatings [18].

Moreover, the technology for abrasive jet machining of metal surfaces was proposed in the paper [19]. The high-speed boriding technology for alloy steel was developed in the article [20]. During thermal spraying of carbide coatings, physical and chemical transformations were analyzed in the research work [21]. The mechanical properties and structural-phase state of wear-resistant coatings were studied in [22]. Finally, the rheological behavior of composite materials in the engineering industry was modeled in [23].

Nevertheless, despite the numerous studies in ensuring wear resistance of multilayer coatings, estimation of the optimal wear depth for multilayer coatings is an urgent scientific problem, which needs solving the scientific gaps in developing an approach for evaluating the mass loss distribution over the thickness of each layer in a multilayer coating.

Thus, the article aims to substantiate the possibility of evaluating the wear depth of a multilayer coating by distributing mass losses of worn layers. For achieving this goal, the following objectives are formulated. Firstly, the mathematical model of determining wear surface and mass losses should be developed. Secondly, an approach for obtaining the mass loss distribution function should be proposed. Next, the proposed methodology should be applied for a particular case study of the multilayer coating based on the nitrogenchroming treatment. Finally, the mass loss ranges and the mass distribution rate should be defined, and the corresponding result should be compared as a percentage with the proposed analytical approach. 
The research directions of solving the stated problem are as follows: X-ray structural analysis, X-ray spectral analysis, metallographic analysis, as well as determination of microhardness and wear resistance.

\section{Materials and Methods}

\subsection{Mathematical Model}

For the case of the cylindrical counterbody, the proposed mathematical model is based on evaluation of the segment area $A B C$ (Figure 1a):

$$
S=\frac{d^{2}}{8}(\varphi-\sin \varphi)
$$

where $S$-area of the segment $A C B$ as the specific cross-sectional area of the worn layer; $d$-the counterbody diameter, $\mathrm{m} ; \varphi$-angle, rad.

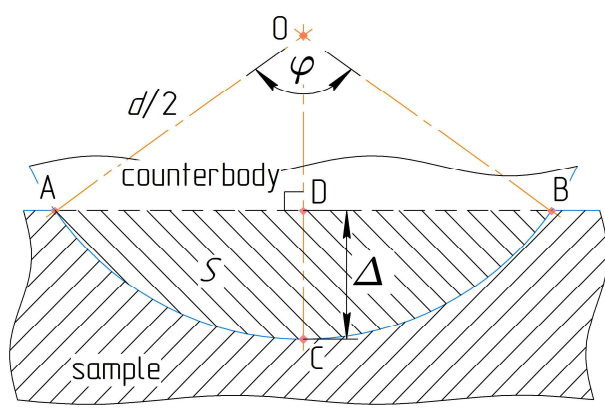

(a)

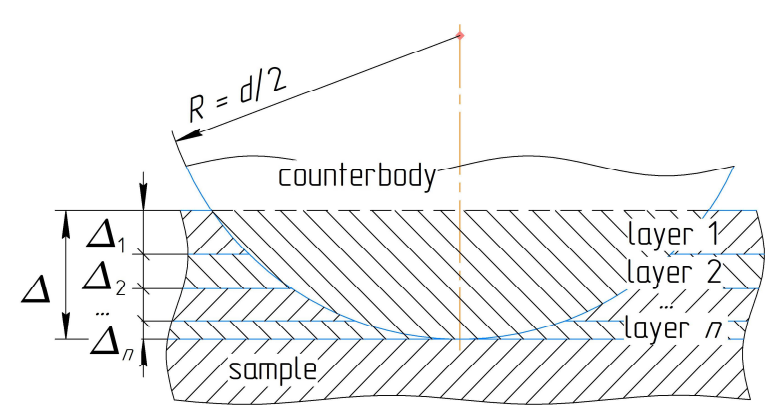

(b)

Figure 1. The design scheme for a single layer (a) and multilayer (b) case studies.

Next, from the triangle $O D A$, it can be obtained the following trigonometric expressions:

$$
\begin{gathered}
\cos \frac{\varphi}{2}=\frac{O D}{O A}=\frac{O C-D C}{O A}=\frac{\frac{d}{2}-\Delta}{\frac{d}{2}}=1-\frac{2 \Delta}{d} \\
\sin \frac{\varphi}{2}=\sqrt{1-\cos ^{2} \varphi}=\sqrt{1-\left(1-\frac{2 \Delta}{d}\right)^{2}}=2 \sqrt{\frac{\Delta}{d}\left(1-\frac{\Delta}{d}\right)} \\
\sin \varphi=2 \sin \frac{\varphi}{2} \cos \frac{\varphi}{2}=4\left(1-\frac{2 \Delta}{d}\right) \sqrt{\frac{\Delta}{d}\left(1-\frac{\Delta}{d}\right)}
\end{gathered}
$$

where $\Delta$-the total wear depth, $\mathrm{m}$.

For simplifying further modeling, the following assumptions are used. Firstly, the total wear depth $\Delta$ is reached gradually. Particularly, for the case study considered below, the ratio of the wear depth to the counterbody diameter is of the order from $10^{-5}$ to $10^{-4}$. In this regard, elastic deformations of layers are not considered.

Secondly, the wear is significantly less than the counterbody diameter $(\Delta<<d)$. This assumption allows us to neglect trigonometric representation using the Maclaurin series [24]:

$$
\sin \varphi \approx \varphi-\frac{\varphi^{3}}{6}
$$

Secondly, the wear of the counterbody is not considered. Finally, numbering from the external layer to the internal one is used.

Therefore, after substitution Equation (2) to dependence (1) and considering expression Equation (3), the segment area in Equation (1) is as follows:

$$
S=\frac{4}{3} d^{2}\left(1-\frac{2 \Delta}{d}\right)^{3}\left[\frac{\Delta}{d}\left(1-\frac{\Delta}{d}\right)\right]^{\frac{3}{2}}
$$


Under the assumption $\Delta<<d$, Equation (4) is simplified significantly:

$$
S \approx \frac{4}{3} \Delta^{\frac{3}{2}} \sqrt{d}
$$

Equation (5) for the specific cross-sectional area allows us to obtain areas for each $k$-th layer (Figure 1b) using the following geometrical dependencies:

$$
\begin{gathered}
S_{1}=\frac{4 \sqrt{d}}{3}\left[\Delta^{\frac{3}{2}}-\left(\Delta-\Delta_{1}\right)^{\frac{3}{2}}\right] ; \\
S_{k}=\frac{4 \sqrt{d}}{3}\left[\left(\Delta-\sum_{j=1}^{k-1} \Delta_{j}\right)^{\frac{3}{2}}-\left(\Delta-\sum_{j=1}^{k} \Delta_{j}\right)^{\frac{3}{2}}\right] ; \\
S_{n}=\frac{4 \sqrt{d}}{3}\left(\Delta-\sum_{j=1}^{n-1} \Delta_{j}\right)^{\frac{3}{2}}
\end{gathered}
$$

where $k$-layer number $(k=\overline{1, n}) ; n$-total number of layers; $\Delta_{j}-j$-th layer thickness, m; $S_{k}$-area of the $k$-th layer, $\mathrm{m}^{2}$.

For the case of the cylindrical counterbody, the mass loss of the segment $A B C$ (Figure 1a) is evaluated as follows:

$$
m=\rho S b=\frac{4 b \sqrt{d}}{3} \rho \Delta^{\frac{3}{2}},
$$

where $b$-the counterbody width, $\mathrm{m} ; \rho$-layer density, $\mathrm{kg} / \mathrm{m}^{3}$.

Since the wear depth $z, \mathrm{~m}$, is permanently increasing, the mass loss distribution should consider this parameter (Figure 2a). In this regard, there are the following options for the maximum depth $z_{\max }$ in comparison with the total thickness of the layers $\Delta_{s}$ (Figure $2 \mathrm{~b}$ ):

1. $z_{\max }<\Delta_{s}$-partial wear of the layer(s) with the total depth of $z=z_{\max }=z_{p}$;

2. $z_{\max }=\Delta_{S}$-full wear of all the layers with the total depth of $z=z_{\max }=\Delta_{s}$;

3. $z_{\max }>\Delta_{s}$-wear of the sample with the total depth of $z=z_{\max }>\Delta_{s}$.

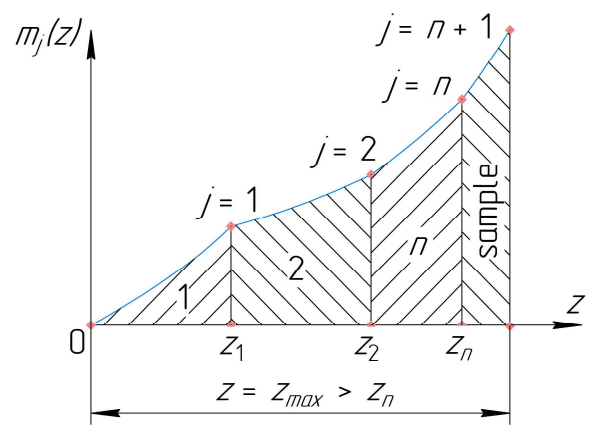

(a)

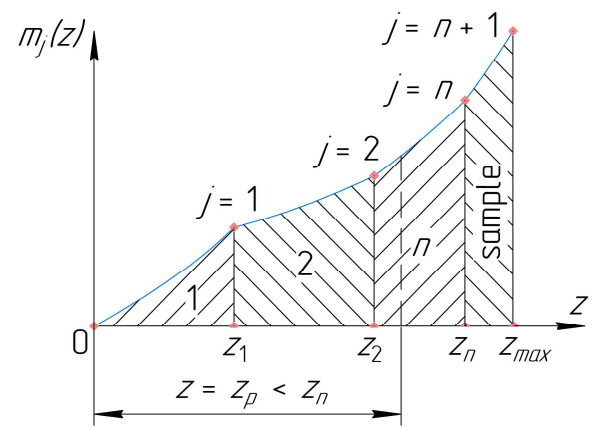

(b)

Figure 2. Mass loss distribution for the cases of $z_{\max }>\Delta_{S}(\mathbf{a})$, and $z_{\max }<\Delta_{S}(\mathbf{b})$.

Notably, different inclination angles are substantiated by different densities of layers. Options 2-3 are unacceptable. In the case of the 1st option, the problem is to evaluate the number $n$ of worn layers from the following condition:

$$
\sum_{j=1}^{n} \Delta_{j} \leq z_{\max }<\sum_{j=1}^{n+1} \Delta_{j}
$$

After considering Equation (6), Equation (7) can be rewritten for each $k$-th layer (Figure 2) and wearing depth $z$ as follows: 


$$
\begin{gathered}
m_{1}(z)=\frac{4 b \sqrt{d}}{3} \rho_{1} z^{\frac{3}{2}} H(z) H\left(\Delta_{1}-z\right) ; \\
m_{k}(z)=\frac{4 b \sqrt{d}}{3}\left[\rho_{1} z^{\frac{3}{2}}-\sum_{j=1}^{k-1}\left(\rho_{j}-\rho_{j+1}\right)\left(z-\sum_{i=1}^{j} \Delta_{i}\right)^{\frac{3}{2}}\right] H\left(z-\sum_{j=1}^{k-1} \Delta_{j}\right) H\left(\sum_{j=1}^{k} \Delta_{j}-z\right),
\end{gathered}
$$

where $\rho_{k}-k$-th layer density, $\mathrm{kg} / \mathrm{m}^{3}$.

Remarkably, the Heaviside functions like $H(z)$ [25] are introduced for discretizing the mass loss distribution for each $k$-th layer. In other words, values outside the layer's range of $z \in\left[z_{j}, z_{j+1}\right]$ are equal to zero.

This approach allows us to evaluate the total mass loss as a sum of mass losses for all layers:

$$
\begin{gathered}
m_{\mathcal{S}}(z)=\frac{4 b \sqrt{d}}{3}\left[\rho_{1} z^{\frac{3}{2}} H(z) H\left(\Delta_{1}-z\right)+\right. \\
\left.+\sum_{k=2}^{n+1}\left[\rho_{1} z^{\frac{3}{2}}-\sum_{j=1}^{k-1}\left(\rho_{j}-\rho_{j+1}\right)\left(z-\sum_{i=1}^{j} \Delta_{i}\right)^{\frac{3}{2}}\right] H\left(z-\sum_{j=1}^{k-1} \Delta_{j}\right) H\left(\sum_{j=1}^{k} \Delta_{j}-z\right)\right]
\end{gathered}
$$

The layer number $(n+1)$ relates to the sample material.

Notably, the total mass can be evaluated as a sum of mass $m_{j}$, $\mathrm{kg}$, for each $j$-th worn layer:

$$
\begin{gathered}
m_{1}=\frac{4 b \sqrt{d}}{3} \rho_{1}\left[z^{\frac{3}{2}}-\left(z-\Delta_{1}\right)^{\frac{3}{2}}\right] \\
m_{j}=\frac{4 b \sqrt{d}}{3} \rho_{j}\left[\left(z-\sum_{i=1}^{j-1} \Delta_{i}\right)^{\frac{3}{2}}-\left(z-\sum_{i=1}^{j} \Delta_{i}\right)^{\frac{3}{2}}\right] \\
m_{n}=\frac{4 b \sqrt{d}}{3} \rho_{n}\left(z-\sum_{i=1}^{n-1} \Delta_{i}\right)^{\frac{3}{2}}
\end{gathered}
$$

Thus, the proposed mathematical model is based on trigonometric relations for the cylindrical sectors and physical relations for the mass of elements for any multilayer coating. This approach has allowed us to determine the estimated wear depth on the current weight loss. However, other characteristics (e.g., yield strength, Young's modulus, hardness, and lubrication-if available) can be considered indirectly by substituting the time-varying dependency for wearing $z(t)$ to Equation (11).

\subsection{A Particular Case Study}

For the practical case study, a three-layer coating obtained by the consequent nitro-

\begin{tabular}{|c|c|c|c|c|}
\hline Layer Number & Density $\mathrm{kg} / \mathrm{m}^{3}$ & Thickness, $\mu \mathrm{m}$ & Microhardness, GPa & Phase Composition \\
\hline & \multicolumn{4}{|c|}{ Multilayer Coating } \\
\hline 1 & 7000 & 3 & 18.2 & $\mathrm{Cr}_{23} \mathrm{C}_{6}$ \\
\hline 2 & 6970 & 4 & 16.2 & $\mathrm{Cr}_{7} \mathrm{C}_{3}$ \\
\hline \multirow[t]{2}{*}{$n=3$} & 6800 & 3 & 8.8 & $\mathrm{Cr}_{2} \mathrm{~N}$ \\
\hline & \multicolumn{4}{|c|}{ Sample } \\
\hline$n+1=4$ & 7840 & - & - & - \\
\hline
\end{tabular}
genchroming of the sample from steel DIN C80W1 (Table 1) has been considered.

Table 1. Density, thickness, microhardness, and phase composition of the protective coating layers after nitrogenchroming: nitriding (temperature $-540{ }^{\circ} \mathrm{C}$, time $-36 \mathrm{~h}$ ) and chroming (temperature$1050{ }^{\circ} \mathrm{C}$, time $-4 \mathrm{~h}$ ).

Determination of the coating thickness was realized on the microhardness tester "PMT3 ". Densities of the individual layers of the coating have been considered according to the data presented in [26]. 
Measurements of the thickness of the diffusion layers and their microhardness were performed not less than in 10-15 view areas. The thickness of the protective coating was considered as a thickness of the white layer. This layer is not etched with a 3\% solution of nitric acid in ethanol. The thickness of the transient zone was estimated as a thickness of the layer, the microhardness of which differs from the microhardness of the main structure of the machining alloy.

Microhardness is determined according to the standard GOST 9450-60 by pressing on the device "PMT-3" ("MTPK-LOMO" Ltd., Saint Petersburg, Russia). Indenter is a quadrangular diamond pyramid with an angle at the top of $136^{\circ}$. The characteristics of microhardness is determined as follows, $\mathrm{kgf} / \mathrm{mm}^{2}$ [27]:

$$
H_{\mu}^{i}=1.854 \frac{P}{D^{2}} \text {, }
$$

where $\mathrm{P}=10-50 \mathrm{~g}$-load; $\mathrm{D}$-imprint diagonal, $\mu \mathrm{m}$.

The counterbody diameter $d=0.30 \mathrm{~m}$, and width $b=0.15 \mathrm{~m}$. The total coating thickness $\Delta_{S}=10 \mu \mathrm{m}$. In the case of the unworn sample $\left(m_{4}=0 \mathrm{mg}\right)$, the mass distribution of each worn layer is as follows (Table 2, Figure 3): $m_{1}=10.0 \mathrm{mg}, m_{2}=10.2 \mathrm{mg}$, and $m_{3}=3.9 \mathrm{mg}$. The total mass loss (as a sum of $m_{j}$ ) is equal to $24.1 \mathrm{mg}$.

Table 2. Mass loss ranges.

\begin{tabular}{ccc}
\hline \multirow{2}{*}{ Wearing Till Layer No. } & \multicolumn{2}{c}{ The Total Mass Losses, $\mathbf{m g}$} \\
\cline { 2 - 3 } & $\min , \boldsymbol{m}_{\boldsymbol{s}}\left(z_{j-1}\right)$ & $\max , \boldsymbol{m}_{\boldsymbol{s}}\left(z_{j}\right)$ \\
\hline 1 & - & 4.0 \\
\hline 2 & 4.0 & 14.2 \\
\hline 3 & 14.2 & 24.1 \\
\hline 4 & 24.1 & 24.1 \\
\hline
\end{tabular}

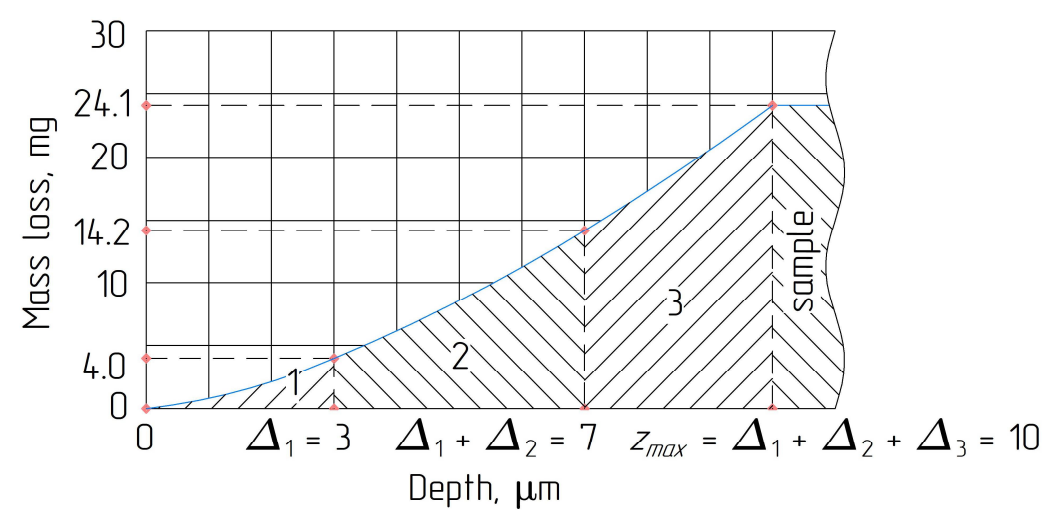

Figure 3. Mass losses distribution.

\subsection{Experimental Equipment}

The application of protective coatings was implemented in two successive stages. The first stage is nitriding, which was carried out in production conditions in a shaft furnace in an ammonia environment (dissociation degree $47-55 \%$; temperature $540{ }^{\circ} \mathrm{C}$; duration $36 \mathrm{~h}$ ).

The second stage is chromizing, which was carried out in a closed reaction space under reduced pressure of the gas phase in a particular installation based on a shaft furnace "SShOL 1.1.6/12" (pressure $0.1 \mathrm{mmHg}$; temperature $1050{ }^{\circ} \mathrm{C}$; duration $4 \mathrm{~h}$ ). The composition of the saturating mixture: $50 \mathrm{~g} / \mathrm{m}^{2}$ of $\mathrm{Cr}, 20 \mathrm{~g} / \mathrm{m}^{2}$ of charcoal, and $6-7 \mathrm{~mL} / \mathrm{m}^{2}$ of carbon tetrachloride $\left(\mathrm{CCl}_{4}\right)$. 
Samples were made from steel DIN C80W1 with the following composition: $0.79 \%$ of C, $0.26 \%$ of $\mathrm{Si}, 0.20 \%$ of $\mathrm{Mn}, 0.20 \%$ of $\mathrm{Cr}$, not more than $0.018 \%$ of S, not more than $0.025 \%$ of $\mathrm{P}$, not more than $0.20 \%$ of $\mathrm{Cu}$, and not more than $0.20 \%$ of $\mathrm{Ni}$.

Wear tests were performed on specially prepared samples after chemical-thermal treatment. Lubricants were removed with detergents. All other contaminants were treated with the finest sandpaper. Degreasing was carried out with ethanol. Contact interaction occurred on the front surface of the sample.

For experimental evaluation of wear resistance under sliding friction without lubrication, the friction machine "MT68-M" (PJSC "Tochpribor", Kharkiv, Ukraine) was used. In [28], the typical research methodology is presented in detail. Steel DIN 66Mn4 (hardened and tempered) is used as the counterbody material with the hardness of HRC 51.

Additionally, the weighting method is applied $[29,30]$. This method allows us to estimate friction intensity by relatively low wearing. According to the standard GOST 23.224-86, the weighting method is used as one of the methods for the determination of wear. In this case, mass losses due to wearing are determined by electronic scales "AXIS ANG220C" ("Himstatus" Ltd., Kharkiv, Ukraine). Notably, experimental research is also carried out using the following laboratory equipment:

- X-ray diffraction analysis is conducted by diffractometer "DRON UM-1" (“MTPKLOMO" Ltd., Saint Petersburg, Russia) in $\mathrm{Cu} K_{\alpha 1}$ radiation using graphite monocrystal monochromator on diffracted beam;

- Metallographic analysis is carried out by microscopes "MIM-8" ("MTPK-LOMO" Ltd., Saint Petersburg, Russia) and "Neophot-21" (Carl Zeiss Jena GmbH, Oberkochen, Germany);

- X-ray spectral analysis is realized using scanning electron microscope "JSM-6490LV" (Tokyo Boeki Ltd., Tokyo, Japan).

Experimental studies are performed using laboratory equipment described above. This equipment allows us to obtain a microstructure in reflected electrons and spectrums for multilayer coatings after chemical-thermal treatment.

\section{Results}

3.1. Microstructure of Coatings after Nitrogenchroming of Steels

\subsubsection{Steel DINC80W1}

For the case of chroming steel DIN C80W1, one-component saturation of steels by chromium leads to the formation of a multilayer coating based on chromium carbides $\mathrm{Cr}_{7} \mathrm{C}_{3}$ and $\mathrm{Cr}_{23} \mathrm{C}_{6}$. On the spectrums for steel DIN C80W1 after chroming, the peaks of Fe, C, Cr (Figure 4), as well as Si, and Mn (Table 3) were fixed. The generalized information about chemical elements is summarized in Table 3.

Table 3. Distribution of chemical elements in the coating for steel DIN C80W1 after chroming (temperature $-1050{ }^{\circ} \mathrm{C}$, time $-4 \mathrm{~h}$ ).

\begin{tabular}{ccccccc}
\hline \multirow{2}{*}{ Spectrum No. } & \multirow{5}{*}{ Distance from the Surface $\mu \mathrm{m}$} & \multicolumn{5}{c}{ Content of Elements, \% Mass } \\
\cline { 3 - 6 } & & $\mathbf{C}$ & $\mathbf{C r}$ & $\mathbf{F e}$ & $\mathrm{Si}$ & Mn \\
\hline 1 & 3.0 & 5.4 & 84.6 & 10.0 & - & - \\
2 & 7.0 & 9.0 & 79.8 & 11.2 & - & - \\
3 & 10.0 & 9.1 & 78.6 & 12.1 & 0.2 & - \\
4 & 50.0 & 0.7 & 1.5 & 95.9 & 1.5 & 0.4 \\
\hline
\end{tabular}

The results presented in Figure $4 a, b$ (qualitative and quantitative spectral analysis of samples after chroming) were obtained from the thickness of the diffusion layers on the scanning electron microscope "JSM-6490LV" (Tokyo Boeki Ltd., Tokyo, Japan). In this case, $X$-ray spectral analysis of samples after chroming and nitrogenchroming on the outside surface of the coating was not performed since the authors preferred the layer-by-layer method on transverse sections. The operating parameters of the stand are as follows: under pressure $5 \mathrm{~Pa}$, accelerating potential difference $10-20 \mathrm{kV}$, amperage 10-15 mA, probe 
diameter 1-2 $\mu \mathrm{m}$. Under these conditions, the penetration depth of the electron beam is in a range of $0.7-1.0 \mu \mathrm{m}$. This fact allowed us to analyze only the outer layer of the coating, the thickness of which is $3 \mu \mathrm{m}$. In turn, the selected scanning method on the cross-sections provides information about all three layers of the coating separately.

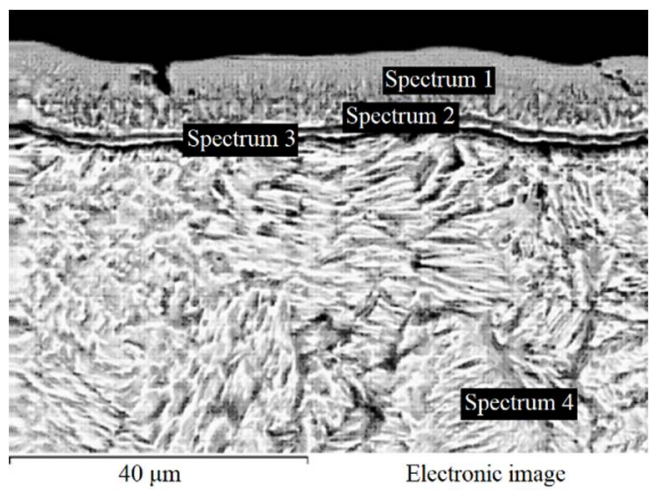

(a)

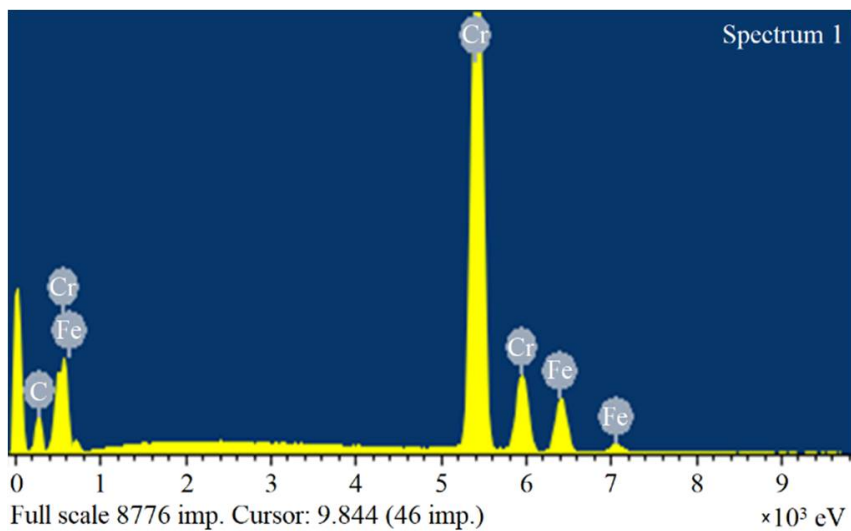

(b)

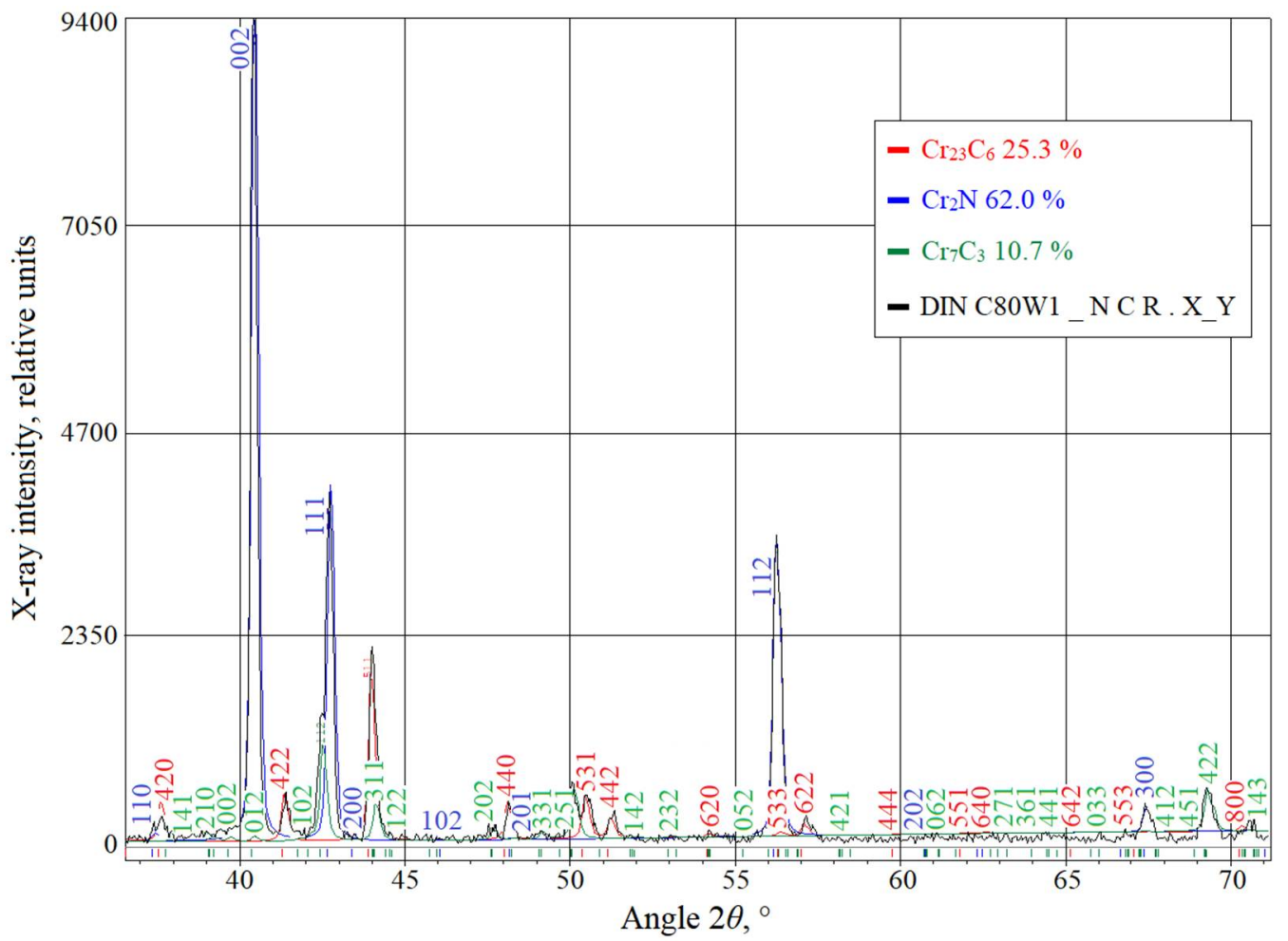

(c)

Figure 4. Microstructure in reflected electrons (a), diffractogram (b), and spectral curves (c) of steel DIN C80W1 after chroming and nitrogenchroming (temperature $-1050^{\circ} \mathrm{C}$, time $-4 \mathrm{~h}$ ).

The phase $\mathrm{Cr}_{23} \mathrm{C}_{6}$ has the maximum content of $\mathrm{Cr}$ (Table 3, Spectrum no. 1), which is $84.6 \%$ mass.

The concentration of Fe decreases from the base $(95.9 \%$, mass) to the outside of the coating $(10.0 \%$, mass). The observed distribution of Fe is accompanied by a decrease in the concentration of $\mathrm{Cr}$ in the direction from the outer side to the inner side of the coating. In turn, the amount of $C$ within the coating is almost unchanged. This fact can be explained by the fact that chromium carbide $\mathrm{Cr}_{7} \mathrm{C}_{3}$ has a narrow region of homogeneity by C (28.5-31.5 at. \%). 
The amount of $\mathrm{Cr}$ in the coating also changes slowly. Notably, $\mathrm{Cr}$ is available in the base of steel DIN C80W1 at a distance of $50 \mu \mathrm{m}$ (Table 3, Spectrum no. 4). In contrast to the behavior of titanium during titanatizing [31], the content of $\mathrm{Cr}$ in the base of the steel after chromizing is greater even at a considerable distance. This comparison indicates greater diffusion activity of $\mathrm{Cr}$ than $\mathrm{Ti}$ in austenite.

According to experimental data on the distribution of chemical elements (Table 3), the average density for each $j$-th layer is determined as follows:

$$
\bar{\rho}_{j}=\sum_{r=1}^{q} \mu_{r}^{(j)} \rho_{r}
$$

where $\mu_{r}^{(j)}$-fraction of $r$-th chemical element in the $j$-th layer (Table 3); $\rho_{r}$-density of $r$-th element, $\mathrm{kg} / \mathrm{m}^{3} ; q$-the total number of chemical elements in a spectrum.

Particularly, for the considered case study, the following average densities have been calculated for layers from $\mathrm{Cr}_{23} \mathrm{C}_{6}, \mathrm{Cr}_{7} \mathrm{C}_{3}, \mathrm{Cr}_{2} \mathrm{~N}$, and steel DIN C80W1, respectively: $\rho_{1}=6983 \mathrm{~kg} / \mathrm{m}^{3}, \rho_{2}=6814 \mathrm{~kg} / \mathrm{m}^{3}, \rho_{3}=6806 \mathrm{~kg} / \mathrm{m}^{3}$, and $\rho_{4}=7738 \mathrm{~kg} / \mathrm{m}^{3}$. These values differ from the initial data (Table 1 ) by $0.2 \%, 2.2 \%, 0.1 \%$, and $1.3 \%$, respectively. Remarkably, such an approach corresponds to the methods for determining the density of multicomponent mixtures [32].

\subsubsection{Steel DIN 105WCr6}

As a result of nitrogenchroming (temperature $-1050{ }^{\circ} \mathrm{C}$, time $-4 \mathrm{~h}$ ) of steel DIN 105WCr6, chromium carbides $\mathrm{Cr}_{23} \mathrm{C}_{6}, \mathrm{Cr}_{7} \mathrm{C}_{3}$, and chromium nitride $\mathrm{Cr}_{2} \mathrm{~N}$ are formed in the coating. Based on the $\mathrm{X}$-ray spectral method for analysis of the coating's carbide layer (Figure 5, Spectrums no. 1-2), the presence of C, Cr, and Fe is established. In the area of the carbide layer (Spectrum no. 3), W of the base for steel DIN 105WCr6, O, and N are available.

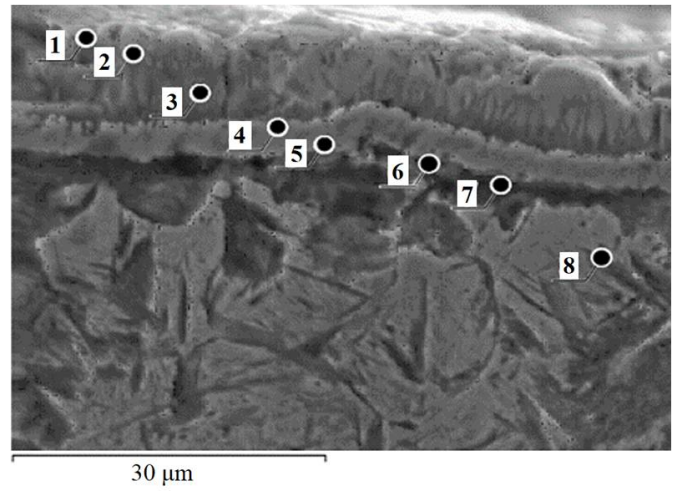

(a)

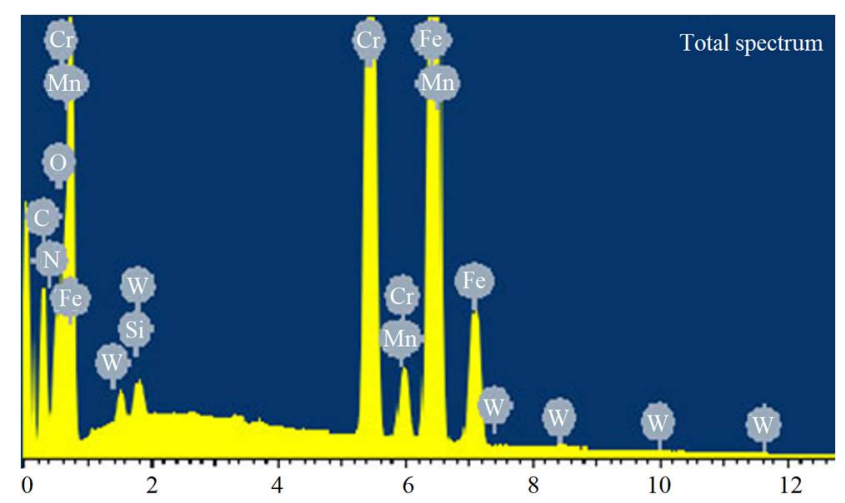

(b)

Figure 5. Microstructure (a) and spectrum (b) for steel DIN 105WCr6 after nitrogenchroming: nitriding (temperature$540{ }^{\circ} \mathrm{C}$, time $-36 \mathrm{~h}$ ) and chroming (temperature $-1050{ }^{\circ} \mathrm{C}$, time $-4 \mathrm{~h}$ ), $\mathrm{Cu}$ emission $K_{\alpha}$ of $0.154 \mathrm{~nm}$.

Figure 5 shows the composition of carbide coatings formed on the surface for steels after single-component saturation of $\mathrm{Cr}$ in a vacuum under reduced pressure. Since both types of steel (DIN C80W1 and DIN 105WCr6) belong to a perlite structural class, the X-ray spectral analysis of the coating has not been carried out.

Quantitative distribution of chemical elements in the coating, transient zone, and base of steel DIN 105WCr6 after nitrogenchroming are presented in Figure 6 and summarized in Table 4. 


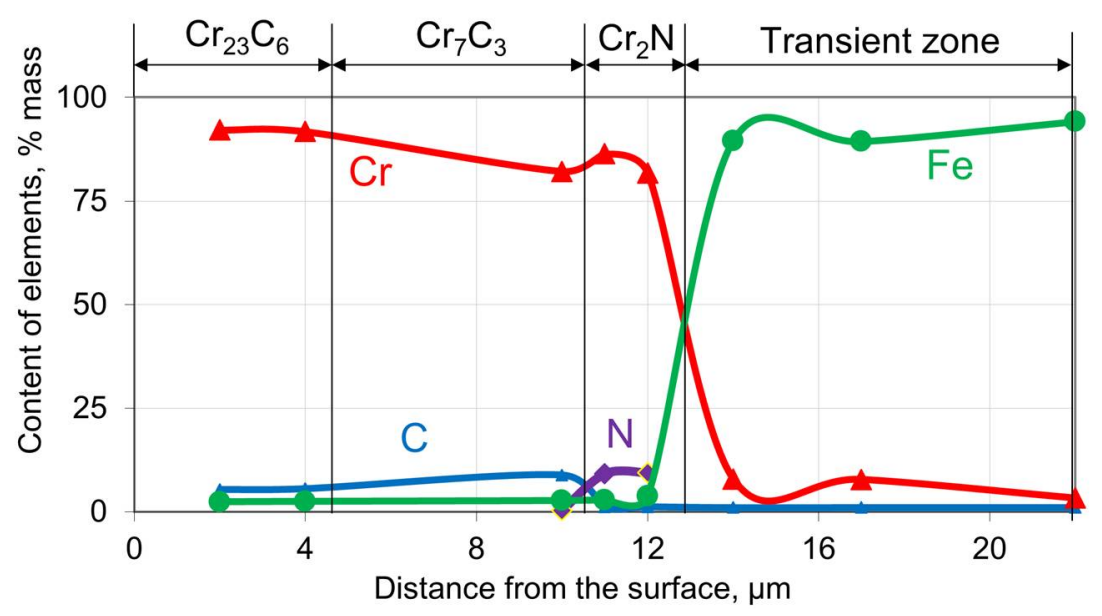

Figure 6. Distribution of chemical elements for steel DIN 105WCr6 after nitrogenchroming: nitriding (temperature $-540{ }^{\circ} \mathrm{C}$, time $-36 \mathrm{~h}$ ) and chroming (temperature $-1050{ }^{\circ} \mathrm{C}$, time $-4 \mathrm{~h}$ ).

Table 4. Distribution of chemical elements for steel DIN 105WCr6 after nitrogenchroming: nitriding (temperature $-540^{\circ} \mathrm{C}$, time $-36 \mathrm{~h}$ ) and chroming (temperature $-1050{ }^{\circ} \mathrm{C}$, time $-4 \mathrm{~h}$ ).

\begin{tabular}{cccccccccc}
\hline \multirow{2}{*}{ Scheme } & \multirow{2}{*}{$\begin{array}{c}\text { Distance from the } \\
\text { Surface, } \boldsymbol{\mu m}\end{array}$} & $\mathbf{C}$ & $\mathbf{N}$ & $\mathbf{C r}$ & $\mathbf{F e}$ & $\mathbf{O}$ & $\mathbf{S i}$ & $\mathbf{M n}$ & $\mathbf{W}$ \\
\cline { 3 - 9 } & 2.0 & 5.4 & - & 92.2 & 2.4 & - & - & - & - \\
\hline 1 & 4.0 & 5.6 & - & 91.8 & 2.5 & - & - & - & 0.1 \\
2 & 10.0 & 8.9 & 0.3 & 82.2 & 2.7 & 0.8 & - & - & 0.1 \\
3 & 11.0 & 1.2 & 9.2 & 86.4 & 2.9 & 1.1 & 0.2 & - & - \\
4 & 12.0 & 1.2 & 9.4 & 81.8 & 3.8 & 3.3 & 0.5 & - & - \\
5 & 14.0 & 1.0 & - & 7.9 & 89.6 & - & 0.6 & 0.4 & 0.5 \\
6 & 17.0 & 1.0 & - & 7.8 & 89.4 & - & 0.9 & 0.4 & 0.5 \\
7 & 22.0 & 1.0 & - & 3.3 & 94.2 & - & - & 0.8 & 0.7 \\
8 & & & & & & &
\end{tabular}

$\mathrm{C}, \mathrm{N}, \mathrm{Cr}, \mathrm{Fe}, \mathrm{O}$, and $\mathrm{Si}$ form nitride layer of the coating after nitrogenchroming of steel DIN 105WCr6. As during chroming, in the case of nitrogenchroming, diffusion of carbide-nitride-forming $\mathrm{Cr}$ into the base of the treated material is observed. The transition zone located under the $\mathrm{Cr}_{2} \mathrm{~N}$ layer contains 6-7 times more $\mathrm{Cr}$ than the corresponding transient zone for steel DIN C80W1 after chroming.

As after chroming, the amount of $\mathrm{C}$ at the cross-section of the carbide layers is almost unchanged. This fact can also be explained by the narrow region of homogeneity of chromium carbide $\mathrm{Cr}_{7} \mathrm{C}_{3}$ by C [33].

In turn, the chromium nitride $\mathrm{Cr}_{2} \mathrm{~N}$ layer has a region of homogeneity from $27.3 \%$ to $33.6 \%$ [34]. This effect allows us to observe the decrease in the solubility of $\mathrm{N}$ in the cross-section from the outer side to the inner side of the layer.

$\mathrm{Si}$ is not detected in the carbide layer. For steel DIN 105WCr6, after nitrogenchroming, diffusion of Fe into the carbide layer is blocked by the nitride layer of the protective coating. This is observed in the characteristic X-rays of chemical elements (Figure 7).

\subsubsection{Comparative Analysis of Coatings}

Nitrogenchroming of carbon and alloy steels leads to the formation of a multilayer coating. According to X-ray diffraction and $\mathrm{X}$-ray spectral analyzes, it is found that two carbide phases $\mathrm{Cr}_{23} \mathrm{C}_{6}$ and $\mathrm{Cr}_{7} \mathrm{C}_{3}$ are formed on the surface.

The characteristic microstructure of steels after saturation by $\mathrm{N}$ and $\mathrm{Cr}$ is obtained using the following Murakami reagent: $10 \mathrm{~g}$ of potassium hexacyanoferrate (III) $\mathrm{K}_{3}\left[\mathrm{Fe}(\mathrm{CN})_{6}\right]$, $10 \mathrm{~g}$ of potassium hydroxide $\mathrm{KOH}$, and $100 \mathrm{~mL}$ of distilled water. 


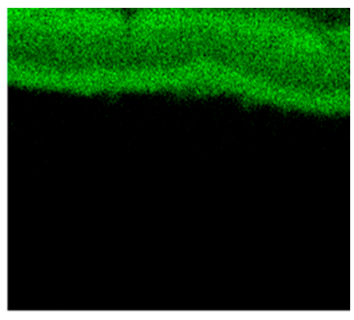

(a)

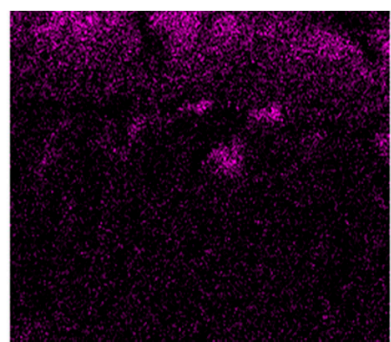

(e)

Figure 8 shows that the outer carbide component of the coating after nitrogenchroming (as after chroming) consists of two separate layers: chromium carbide $\mathrm{Cr}_{23} \mathrm{C}_{6}$ is formed externally; chromium carbide $\mathrm{Cr}_{7} \mathrm{C}_{3}$ is formed closer to the base material.

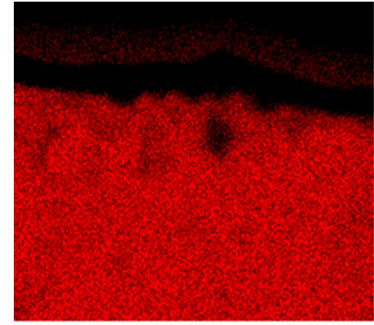

(b)

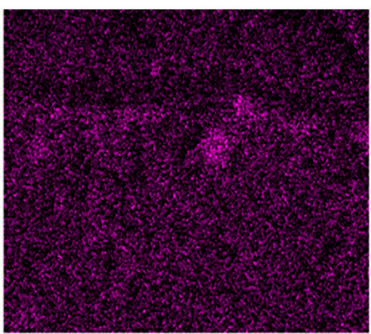

(f)

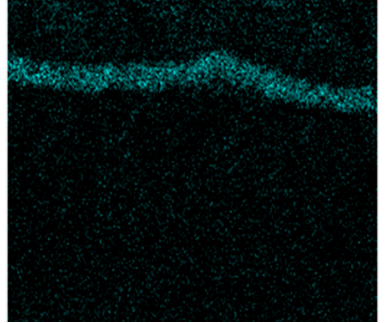

(c)

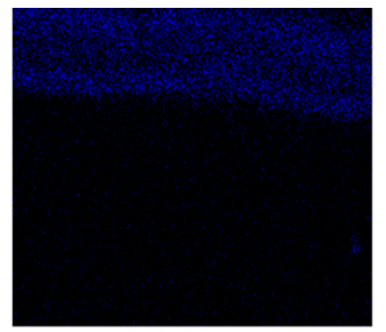

(g)

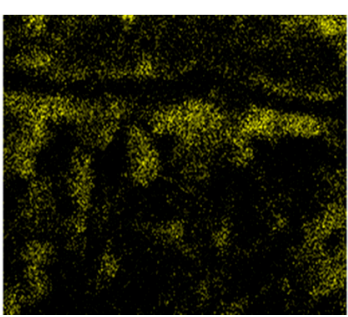

(d)

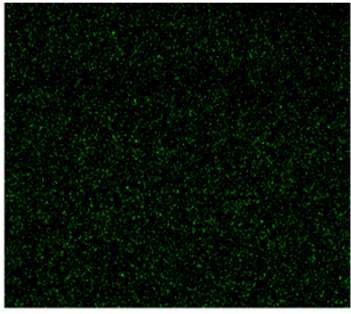

(h)

Figure 7. Distribution of elements along the plane of the section in the characteristic X-ray radiation of $\mathrm{Cr}(\mathbf{a}), \mathrm{Fe}(\mathbf{b}), \mathrm{N}$ (c), C (d), O (e), Si (f), Mn (g), and W (h) for steel DIN 105WCr6 after nitrogenchroming: nitriding (temperature-540 ${ }^{\circ} \mathrm{C}$, time $-36 \mathrm{~h}$ ) and chroming (temperature $-1050{ }^{\circ} \mathrm{C}$, time $-4 \mathrm{~h}$ ).

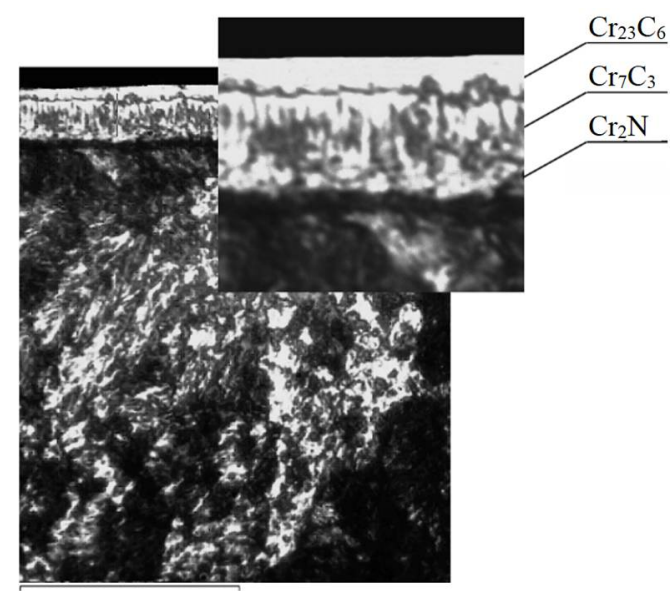

$50 \mu \mathrm{m}$

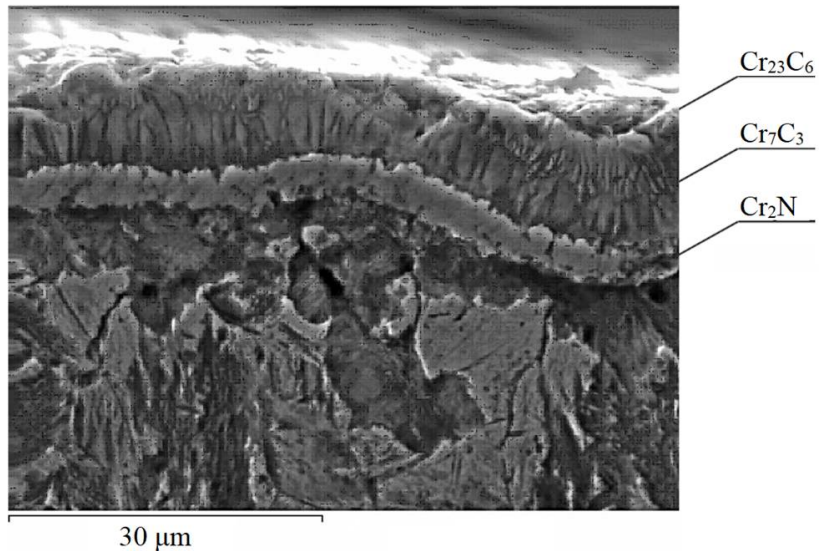

(b)

(a)

Figure 8. Microstructures of steels DIN 100Cr6 (a) and DIN 105WCr6 (b) after nitrogenchroming: nitriding (temperature$540{ }^{\circ} \mathrm{C}$, time $-36 \mathrm{~h}$ ) and chroming (temperature $-1050{ }^{\circ} \mathrm{C}$, time $-4 \mathrm{~h}$ ).

After etching the metal, the microstructure of the chromium carbide $\mathrm{Cr}_{7} \mathrm{C}_{3}$ zone acquires a columnar character. The direction of these crystals coincides with the diffusion direction of the carbide-forming elements.

After nitrogenchroming, a layer whose phase composition corresponds to chromium nitride $\mathrm{Cr}_{2} \mathrm{~N}$ is located under the carbide layer of the protective coating. The nitride layer detected by the Murakami reagent is a solid homogeneous white band. It has a clear interfacial surface with the base and carbide layers. 


\subsection{Wear Resistance of Steel DIN C80W1 after Chemical-Thermal Treatment}

The tests were performed on a friction machine "MT-68" (PJSC "Tochpribor", Kharkiv, Ukraine), which allowed us to fix the friction force on which the coefficient of friction was calculated. The friction coefficient was defined as the ratio of the friction force during the test to the load set by the loading device.

Steel DIN 66Mn4 (hardened and tempered) is used as the counterbody material with the hardness of HRC 51. The counterbody diameter is $300 \mathrm{~mm}$, and the width-150 mm. Velocity is equal to $4 \mathrm{~m} / \mathrm{s}$, and acting force- $40 \mathrm{~N}$. The thickness and density for each layer of the multilayer coating are presented previously in Table 1. Before experiments, the sample and the counterbody were cleaned carefully by acetone.

As the abrasive is individual particles of the coating separated from the base during the test. This is proven by the fact that in the wear holes of samples from steel DIN C80W1 after nitrogenchroming, microcutting lines directed along the friction are observed. This fact characterizes the abrasive type of wear. The abrasive is individual particles of the coating separated from the base during the test. This statement is based on studying the friction surface for the samples using the metallographic and X-ray spectral methods after tribomechanical tests.

The distance between the cutting traces (traces of microcutting formed after the test, in other words, scratches) is significant. Therefore, according to the used test approach, the abrasive nature of wear is not decisive.

After the wear test of steel DIN C80W1 with protective coatings, the surface of the counterbody from steel DIN 66Mn4 is relatively smooth. The surface of the counterbody from steel DIN 66Mn4 for the wear testing of steel DIN C80W1 with the protective coating is smooth. Irregularities in the test path are uniform in depth. Adhesion of steel surfaces was not established. This fact indicates the invariance of the tested coatings to the counterbody material. Wear intensity is determined by the loss of mass for the sample (Figure 9).

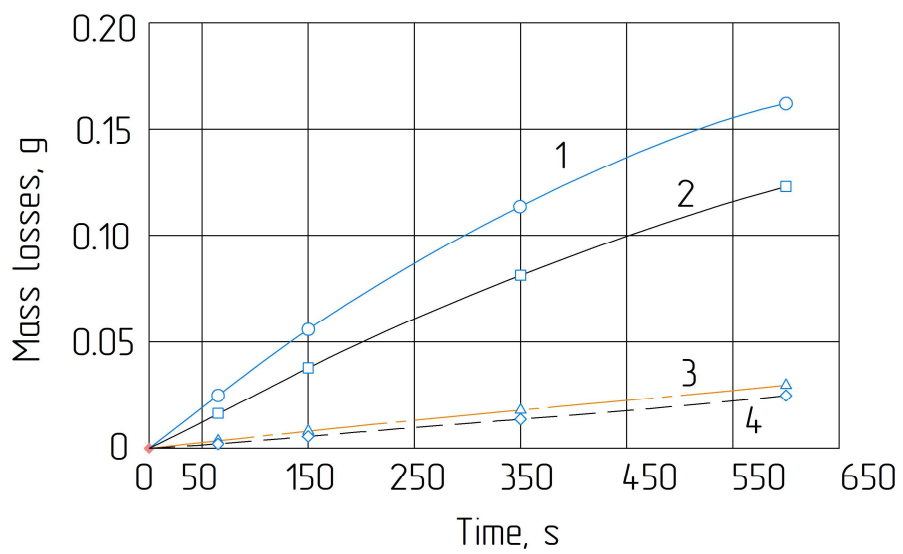

Figure 9. The dependence of mass losses for steel DIN C80W1 with wear-resistant coatings on time under sliding friction conditions without lubrication (force-40 N, velocity-4 m/s): 1 -without treatment; 2-nitriding; 3-chroming; 4-nitrogenchroming.

The duration of the wear test has been chosen as follows. Mainly, for the particular case study, the test has shown that under the loading parameters (no lubrication, force$40 \mathrm{~N}$, and velocity $-4 \mathrm{~m} / \mathrm{s}$ ), the samples had been worn to the base within $600 \mathrm{~s}$. Therefore, this time has been chosen as the duration of the wear test.

Experimentally obtained data graphically presented in Figure 9 shows that in the case of nitrogenchroming, after $600 \mathrm{~s}$ of wearing all coating layers (Table 1), the total mass loss is $0.025 \mathrm{~g}$, which differs by $3.6 \%$ the corresponding value of $24.1 \mathrm{mg}$ obtained theoretically.

For determining the impact of sliding parameters on wear resistance, studies of the dependence for the friction coefficient on the test time have been carried out (Figure 10). 


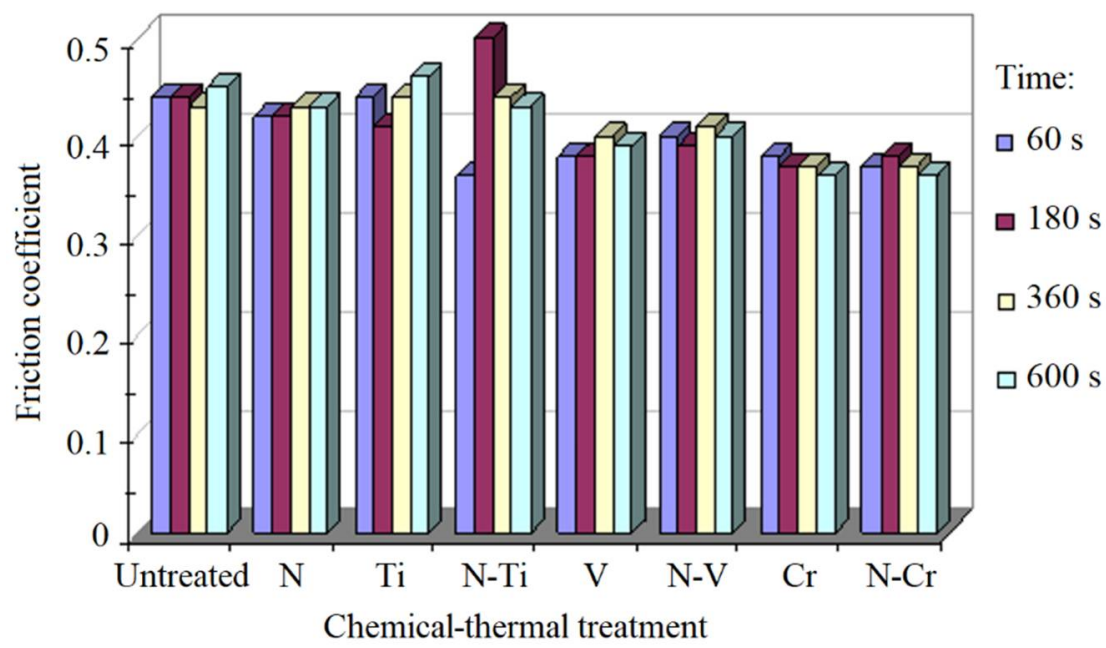

Figure 10. The dependence of friction coefficient for the contact pair "steel DIN C80W1—steel DIN $66 \mathrm{Mn} 4$ " after different treatment modes on time under conditions of sliding friction without lubrication.

Remarkably, the friction coefficient was defined as the ratio of the friction force to the load applied by the loading device.

It is known that nitriding increases wear resistance and reduces the friction coefficient for stainless steels at normal and elevated temperatures [35,36]. There are results, according to which nitrided steels have 2-4 times less wear than cemented after hardening and lowtemperature tempering. However, there are cases when the positive effect of nitriding on wear resistance is absent. The inconsistency of these data is since different authors tested the samples in different conditions. Particularly, some results were obtained under sliding friction without lubrication, others-under rolling friction. The deflected mode in the contact zone under friction conditions for these two cases are different. Additionally, the structure and properties of the nitrided layer can be significantly different, even for steels of the same grade. As a result, differences in the results of microhardness, wear, and corrosion resistance can be possible.

It is shown that during $180 \mathrm{~s}$ of the wear test, weight loss of steel DIN C80W1 with single-layer and multilayer coatings differs slightly. During the wear process, there is a linear dependence of the decrease in the mass of the samples on the test duration. This fact indicates uniform wear of nitride-carbide coatings. However, the nature of the change in wear under different test conditions is slightly different: under load $40 \mathrm{~N}$, and velocity $4 \mathrm{~m} / \mathrm{s}$, there is smoother wear in the early stages, in contrast to more stringent test conditions (load $60 \mathrm{~N}$, and velocity $4 \mathrm{~m} / \mathrm{s}$ [27]). Additionally, it should be noted that under the test conditions of load $40 \mathrm{~N}$, and velocity $4 \mathrm{~m} / \mathrm{s}$, steel DIN C80W1 has the least wear after nitrogenchroming.

Therefore, an increase in test duration decreases the friction coefficient for the samples with coatings. Steel DIN C80W1 has the lowest friction coefficient after chromizing and nitrogenchroming. As a result of tests for steel DIN C80W1 under sliding friction without greasing, the following sequence of treatments in ascending order of the friction coefficient is observed: nitrogenchroming, chroming, vanadizing, nitrogenvanadizing, nitrogentitanizing, titanizing, and nitriding.

The sufficiently high wear resistance of steel DIN C80W1 after nitriding can be explained by the heterogeneous structure of iron nitrides with incoherent inclusions [37]. Particularly, it is known that the nitride layer formed during nitriding is resistant to temperatures above $500{ }^{\circ} \mathrm{C}$.

The increase in wear resistance of steel DIN C80W1 after diffusion metallization compared to steel without treatment can be explained by increased microhardness and relatively lower friction coefficient. Comprehensive treatment by two components compared to one leads to an increase in wear resistance by 1.2-1.5 times. Notably, in the first 150-200 s, all 
coatings are worn to the base in the central contact zone. Then, the composition "steel DIN C80W1-carbide-nitride" works. It is established that during friction, complex oxides of iron and saturating elements are formed on the surface. Simultaneously, the transfer of elements of a counterbody to the friction zone is observed.

For steel DIN C80W1, the following sequence of treatments in ascending order of the wear resistance can be placed: nitriding, titanizing, nitrogentitanizing, vanadizing, nitrogenvanadizing, chromizing, and nitrogenchroming. Nitrogenchroming increases the wear resistance of steel DIN C80W1 by 2.1 times compared to chromizing.

The best wear resistance of steel DIN C80W1 is observed after nitrogenchroming. The high wear resistance of coatings $\mathrm{Cr}_{23} \mathrm{C}_{6} \rightarrow \mathrm{Cr}_{7} \mathrm{C}_{3} \rightarrow \mathrm{Cr}_{2} \mathrm{~N}$ is determined by low friction coefficient and significant ductility, as evidenced by low microfragility. The low coefficient of friction for steel DIN C80W1 after nitrogenchroming can be explained by forming the secondary phases during the friction. These phases act as a lubricant between the coating and the counterbody. Reducing the friction coefficient between the machined workpiece and the coating reduces the temperature and the cutting force. As a result, vibrations are reduced, and lower surface roughness is provided.

Overall, the nature of the change in wear differs slightly under different test conditions. Particularly, in the force $40 \mathrm{~N}$ and velocity $4 \mathrm{~m} / \mathrm{s}$, smoother wear in the early stages than more stringent test conditions (e.g., force-60 N, velocity $-4 \mathrm{~m} / \mathrm{s}$ [27]). Overall, steel DIN C80W1 has the lowest wear intensity after nitrogenchroming.

\section{Discussion}

Notably, existing mathematical models are based mainly on the contact interaction model of a single-layer coating with a counterbody. They are based predominantly on a simplified Hertz model for contact interaction [38]. As a result, they allow one to determine the wear intensity of a single-layer coating over time asymptotically.

However, in the proposed mathematical model, an attempt was made to estimate the total depth of wear by losing the sample's mass. As a result, a generalized mathematical model for multilayer coatings with any number of layers with different properties has been proposed. This model also considers the non-uniformity of the layer thicknesses for the case of a cylindrical counterbody. Notably, the proposed approach also allows us to determine the number of the last worn layer at a given moment.

Thus, the friction coefficient for the samples with coatings decreases in time. The lowest friction coefficient for steel DIN C80W1 is observed after chroming and nitrogenchroming. As a result of experiments under sliding friction conditions without lubrication, the following sequence of chemical-thermal treatments can be arranged by an increase in friction coefficient: nitrogenchroming, chroming, vanadizing, nitriding, nitrogentitanizing, and titanizing.

The following properties determine the high wear resistance of coatings $\mathrm{Cr}_{23} \mathrm{C}_{6} \rightarrow$ $\mathrm{Cr}_{7} \mathrm{C}_{3} \rightarrow \mathrm{Cr}_{2} \mathrm{~N}$. First, there are a relatively low friction coefficient and significant ductility due to low microfragility. The low friction coefficient for steel DIN C80W1 after nitrogenchroming can be explained by forming secondary phases acting as a lubricant between the coating and the counterbody. A decrease in friction coefficient between treated material and the coating leads to decreased temperature and cutting force. As a result, vibrations are reduced, and the surface of the increased purity will be expected. This means that the parts to be machined with the proposed protective coating will result in lower surface roughness.

Improvement of the wear resistance for steel DIN C80W1 after diffusion metallization (compared with steel without processing) can be explained by increased microhardness and lower friction coefficient. Comprehensive two-component treatment compared with a single-component one leads to increased wear resistance 1.2-1.5 times. Notably, under the experimental conditions, all coatings are destroyed to the base for the first 150-200 s of wearing in the central contact zone. After, the composition "steel DIN C80W1—carbide/nitride" acts. Additionally, it has been established that because of friction, complex oxides of Fe 
and saturating elements are formed on the surface. Simultaneously, chemical elements of the counterbody material are transferred to a friction zone.

The following sequence of chemical-thermal treatments can be arranged by increasing the wear resistance of steel DIN C80W1 after saturation: nitriding, chroming, and nitrogenchroming. Particularly, under sliding friction conditions without lubrication, the wear resistance of steel DIN C80W1 after nitrogenchroming is 2.1 times more than after chroming.

At temperatures $277-527^{\circ} \mathrm{C}$, the hardness of chromium carbides is higher than the hardness of titanium carbide [39-41]. In this regard, the best wear resistance is inherent in steel DIN C80W1 after nitrogenchroming. Additionally, the effect of load on the wear intensity for steels after different types of chemical-thermal treatment has been studied. An increase in the load by 1.5 times leads to increased wearing of steel DIN C80W1, after nitrogentitanizing — by 5.3 times, and titanizing — by 5.4 times [29].

Nitriding increases wear resistance and reduces the friction coefficient of stainless steel at normal and elevated temperatures [36,42,43]. Even though nitrided steels have $2-4$ times less wear than cemented after hardening and low-temperature tempering, there are cases when the positive effect of nitriding on wear resistance is absent. The inconsistency of the data is because different researchers tested the samples under different conditions. Some results were obtained under conditions of sliding friction without lubrication, othersunder rolling friction. As a result, the deflected mode in the contact zone under friction is different. Moreover, the structure and properties of the nitrided layer can be different even for similar steels. These facts determine the difference in the results of microhardness, wear resistance, and corrosion resistance.

Additionally, many processes occur on friction surfaces: heat and mass flow, physicochemical processes of interaction of bodies with the environment, deformations, structural and phase transformations [44,45]. However, a simplified wear mechanism [46] can be described as follows. Shear stress occurs at the points of local contact "coveragecounterbody". This stress exceeds the elastic limit while an increase in the material temperature. As a result, a breakdown of material from the tops of the protrusions occurs. Simultaneously, the contact surface remains clean and chemically active. As a result, numerous microbondings of tangent surfaces are alternately formed and destroyed, while the mechanical energy is converted into heat. As a result of a local increase in temperature, oxides of the coating elements and the base occur. Wear is accelerated permanently due to the abrasive action of detached particles of contact material. These effects lead to an overall increase in friction, increased energy consumption, and wear.

The high wear resistance of two-layer coatings can be explained as follows. The nitride-carbide coating has a higher bond strength and chemical inertness than a singlelayer carbide coating of transition elements $[47,48]$. A decrease in friction coefficient between the counterbody and the coating is due to the coating and oxide films' composition during friction. As a result, a model of antifriction material is formed: solid particles of fine carbides [49] and nitrides [50,51] in the viscous base. Moreover, despite the higher microhardness of steel DIN C80W1 after nitrogentitanizing compared to nitrogenchroming, the lower wear of the last one can be explained by greater microstrength and lower microfragility.

\section{Conclusions}

Thus, a comprehensive approach for evaluating the wear depth for multilayer coatings has been proposed. This approach is based on the developed mathematical model of determining wear surface and mass losses. As a result, the methodology for obtaining the mass loss distribution has been proposed. Particularly, a new mathematical model for calculating the wear of steel DIN C80W1 after nitrogenchroming is developed, which considers different cross-sections and densities of layers.

The results of X-ray spectral analysis of steel after a comprehensive saturation by nitrogen and chromium show that a small amount of base iron diffuses through the 
nitride layer into the carbide one. In this case, the amount of iron in the carbide layer of the multilayer coating is much less than in the corresponding carbide layer of a singlelayer coating.

Notably, the nitride layer acts as a barrier, inhibiting the diffusion of iron to the surface. By increasing the solubility of iron in the carbide layers, the protective coatings after complex treatment can be arranged as $\mathrm{Cr}_{23} \mathrm{C}_{6}-\mathrm{Cr}_{7} \mathrm{C}_{3}$. Despite this fact, chromium diffuses through the carbide and nitride layers deep into the steels. In this case, a transient zone is formed.

For steel DIN C80W1, it is experimentally confirmed that the maximum wear resistance under sliding friction without greasing occurs after nitriding. The best indicators of wear resistance are observed after nitriding. The high wear resistance of coatings $\mathrm{Cr}_{23} \mathrm{C}_{6}$ $\rightarrow \mathrm{Cr}_{7} \mathrm{C}_{3} \rightarrow \mathrm{Cr}_{2} \mathrm{~N}$ is determined by low friction coefficient and significant ductility.

The low coefficient of friction for steel DIN C80W1 after nitrogenchroming can be explained by forming the secondary phases during the friction. These phases act as a lubricant between the coating and the counterbody. Reducing the friction coefficient between the machined workpiece and the coating reduces the temperature and the cutting force. As a result, vibrations are reduced, and lower surface roughness is provided.

The difference of $3.6 \%$ between the results obtained analytically and experimentally indicates the correctness of the proposed approach and the reliability of the proposed mathematical model.

Finally, the obtained results will be helpful for the development of chemical-thermal treatment technologies and practical applications in designing cutting tools, strengthening of metal parts, and ensuring the reliability and durability of tools and highly loaded units of machines (e.g., shafts, bearing supports, bushing parts, and couplings).

Author Contributions: Conceptualization, I.P. and N.K.; methodology, I.P., N.K., and V.I.; software, V.I. and J.D.; validation, J.Z. and K.K.; formal analysis, N.K. and K.K.; investigation, I.P., N.K., and K.K.; resources, J.D.; data curation, J.Z.; writing—original draft preparation, I.P.; writing—review and editing, V.I.; visualization, K.K.; supervision, I.P.; project administration, I.P. and J.D.; funding acquisition, J.Z. and J.D. All authors have read and agreed to the published version of the manuscript.

Funding: This work was supported by the Slovak Research and Development Agency under the contract No. APVV-20-0514. This research was also supported by grant VEGA 1/0080/20.

Institutional Review Board Statement: Not applicable.

Informed Consent Statement: Not applicable.

Data Availability Statement: The data presented in this study are available on request from the corresponding author.

Acknowledgments: The research has been partially carried out within the research work "Creation of new granular materials for nuclear fuel and catalysts in the active hydrodynamic environment" (No. 0120U102036, Sumy State University) ordered by the Ministry of Education and Science of Ukraine. The research has also been conducted to fulfill the objectives of the perspective development plan within the scientific direction "Technical Sciences" at Sumy State University. The authors appreciate the support of the International Association for Technological Development and Innovations.

Conflicts of Interest: The authors declare no conflict of interest.

\section{References}

1. Pavlenko, I.; Saga, M.; Kuric, I.; Kotliar, A.; Basova, Y.; Trojanowska, J.; Ivanov, V. Parameter Identification of Cutting Forces in Crankshaft Grinding Using Artificial Neural Networks. Materials 2020, 13, 5357. [CrossRef] [PubMed]

2. Krol, O.; Sokolov, V. Parametric Modeling of Gear Cutting Tools. In Proceedings of the International Scientific-Technical Conference Manufacturing, Poznan, Poland, 19-22 May 2019. [CrossRef]

3. Zhou, W.; Lin, J.; Feng, F.; Ma, Y.; Zha, H.; Ji, W.; Jiang, E.; Cai, Z.; Feng, P. Performance improvement of carbide cutting tool for Ti6Al4V alloys using electromagnetic treatment. Int. J. Adv. Manuf. Technol. 2021, 113, 1547-1560. [CrossRef]

4. Parfenov, V.D.; Basova, G.D. Surface coating metrology of carbides of cutting tools. IOP Conf. Ser. Earth Environ. Sci. 2017, 87, 82036. [CrossRef] 
5. Shvets, S.V.; Astakhov, V.P. Effect of Insert Angles on Cutting Tool Geometry. J. Eng. Sci. 2020, 7, A1-A6. [CrossRef]

6. Gorlenko, A.O.; Davydov, S.V.; Shevtsov, M.Y.; Boldyrev, D.A. Wear-Resistance Increase of Friction Surfaces of Steel Machine Parts by Electro-Mechanical Hardening. Steel Transl. 2019, 49, 800-805. [CrossRef]

7. Ye, H.; Le, F.; Wei, C.; Ye, K.; Liu, S.; Wang, G. Fatigue crack growth behavior of Ti-6Al-4V alloy fabricated via laser metal deposition: Effects of building orientation and heat treatment. J. Alloy. Compd. 2021, 868, 159023. [CrossRef]

8. Storozhenko, M.; Umanskyi, O.; Tarelnyk, V.; Koval, O.; Gubin, Y.; Mikulina, M.; Martsenyuk, I.; Kostenko, O.; Kurinna, T. Structure and Wear Resistance of FeNiCrBSiC-MeB2 Electrospark Coatings. Powder Met. Met. Ceram. 2020, 59, 330-341. [CrossRef]

9. Svirzhevskyi, K.; Zabolotnyi, O.; Tkachuk, A.; Zablotskyi, V.; Cagáňová, D. Methods of Evaluating the Wear Resistance of the Contact Surfaces of Rolling Bearings. In Proceedings of the Grabchenko's International Conference on Advanced Manufacturing Processes, InterPartner 2020, Odessa, Ukraine, 8-11 September 2020. [CrossRef]

10. Dhafer, W.A.-R.; Kostyk, V.; Glotka, A.; Chechel, M. The choice of the optimal temperature and time parameters of gas nitriding of steel. East. Eur. J. Enterp. Technol. 2016, 3, 44-50. [CrossRef]

11. Development of alloy resistant in conditions of abrasive wear. Funct. Mater. 2021, 27, 170-177. [CrossRef]

12. Pogrebnjak, A.; Sobol', O.; Beresnev, V.; Turbin, P.; Kirik, G.; Makhmudov, N.; Il'Yashenko, M.; Shypylenko, A.; Kaverin, M.; Tashmetov, M.; et al. Phase Composition, Thermal Stability, Physical and Mechanical Properties of Superhard on Base Zr-Ti-Si-N Nanocomposite Coatings. Ceram. Eng. Sci. Proc. 2010, 31, 127-138. [CrossRef]

13. Murčinková, Z.; Baron, P.; Tiňo, L.; Pollák, M.; Murčinko, J. Research and analysis of stress distribution in multilayers of coated tools. Int. J. Mater. Res. 2017, 108, 495-506. [CrossRef]

14. Lehocka, D.; Klich, J.; Botkova, D.; Simkulet, V.; Foldyna, J.; Krejci, L.; Storkan, Z.; Kepic, J.; Hatala, M. Comparison of ultrasonically enhanced pulsating water jet erosion efficiency on mechanical surface treatment on the surface of aluminum alloy and stainless steel. Int. J. Adv. Manuf. Technol. 2019, 103, 1647-1656. [CrossRef]

15. Kharlamov, Y.; Sokolov, V.; Krol, O.; Romanchenko, O. Research of the Influence of Conditions of D-gun Spraying on Properties of Tungsten and Chromium Carbides Coatings. In Proceedings of the Grabchenko's International Conference on Advanced Manufacturing Processes, InterPartner 2020, Odessa, Ukraine, 8-11 September 2020. [CrossRef]

16. Kulesh, E.A.; Piliptsou, D.G.; Rogachev, A.V.; Hong, J.X.; Fedosenko, N.N.; Kolesnyk, V. Boron-Carbon Coatings: Structure, Morphology, and Mechanical Properties. J. Eng. Sci. 2020, 7, C1-C9. [CrossRef]

17. Tarelnyk, V.; Gaponova, O.; Myslyvchenko, O.; Sarzhanov, B. Electrospark Deposition of Multilayer Coatings. Powder Met. Met. Ceram. 2020, 59, 76-88. [CrossRef]

18. Tarelnyk, V.B.; Gaponova, O.P.; Konoplianchenko, Y.V.; Martsynkovskyy, V.S.; Tarelnyk, N.V.; Vasylenko, O.O. Improvement of Quality of the Surface Electroerosive Alloyed Layers by the Combined Coatings and the Surface Plastic Deformation. I. Features of Formation of the Combined Electroerosive Coatings on Special Steels and Alloys. Met. I Noveishie Tekhnologii 2019, 41, 47-69. [CrossRef]

19. Sychuk, V.; Zabolotnyi, O.; Somov, D. Technology of Effective Abrasive Jet Machining of Parts Surfaces. In Proceedings of the International Conference on Design, Simulation, Manufacturing: The Innovation Exchange, DSMIE 2018, Sumy, Ukraine, 11-14 June 2018. [CrossRef]

20. Костик, K.O. Development of the high-speed boriding technology of alloy steel. East. Eur. J. Enterp. Technol. 2015, 6, 8-15. [CrossRef]

21. Kharlamov, O.Y.; Sokolov, I.V.; Krol, O.S.; Romanchenko, O.V. Analysis of physical and chemical transformations during thermal spraying of coatings based on carbides of tungsten and chromium. IOP Conf. Ser. Mater. Sci. Eng. 2020, 985, 12036. [CrossRef]

22. Physical-mechanical properties and structural-phase state of nanostructured wear-resistant coatings based on nitrides of refractory metals Ti and Zr. Funct. Mater. 2019, 26, 548-555. [CrossRef]

23. Knapčíková, L.; Dupláková, D.; Radchenko, S.; Hatala, M. Rheological behavior modelling of composite materials used in engineering industry. TEM J. 2017, 6, 242-245. [CrossRef]

24. Doeva, O.; Masjedi, P.K.; Weaver, P.M. A semi-analytical approach based on the variational iteration method for static analysis of composite beams. Compos. Struct. 2021, 257, 113110. [CrossRef]

25. Yukhymenko, L.M.; Pavlenko, I.; Pitel, J.; Mizakova, J.; Ostroha, R.; Bocko, J. Ensuring the Reliability of Pneumatic Classification Process for Granular Material in a Rhomb-Shaped Apparatus. Appl. Sci. 2019, 9, 1604. [CrossRef]

26. Zefirov, N.S.; Kulov, N.N. Chemical Encyclopedia; Great Russian Encyclopedia: Moscow, Rusia, 1998.

27. Kurylo, N.A.; Khyzhnyak, V.G.; Sigova, V.I. Ultrafine Diffusion Carbonitride Coatings on Steels and Hard Alloys: Monograph; Sumy Regional Institute of Postgraduate Education: Sumy, Ukraine, 2011.

28. Inoue, S.; Uchida, H.; Hioki, A.; Koterazawa, K.; Howson, R.P. Structure and composition of (Ti, Al)N films prepared by r.f. planar magnetron sputtering using a composite target. Thin Solid Films 1995, 271, 15-18. [CrossRef]

29. Kaporin, V.A. Improvement of the Technology for Restoration of Shafts in Agricultural Machinery during Dimensional Pro-cessing of Microporous Coatings on an Iron Base. Ph.D. Thesis, Polzunov Altai State Technical University, Novosibirsk, Rusia, 2020.

30. Korobov, Y.S.; Filippov, M.A.; Makarov, A.V.; Verkhorubov, V.S.; Nevezhin, S.V.; Kashfullin, S.V. Resistance of deposited layers and sprayed coatings with a metastable austenite structure against abrasive and adhesive wear. Izv. Samara Sci. Cent. Russ. Acad. Sci. 2015, 17, 224-230.

31. Hignjak, V.G.; Calashnicov, G.Y.; Harchenko, N.A.; Hovorun, T.P.; Hignjak, O.V.; Dolgikh, V.Y.; Holyshevskiy, O.O. The structure, composition and properties of nitrided alloys after diffusion metallization. J. Nano Electron. Phys. 2015, 7, 04033-1-04033-6. 
32. Moiseev, A.V. Calculation Methods for Determining the Physicochemical Properties of Hydrocarbon Systems, Oils and Pe-troleum Products: Examples and Tasks; Komsomolsk-on-Amur State Technical University: Komsomolsk-on-Amur, Russia, 2010.

33. Ma, Y.-D.; Guo, M.-Y.; Li, W.; Yang, Y.; Gao, P.-Y.; Cui, Y.-H.; Sun, W.-W.; Wang, Y.-W.; Wang, L.; Dong, Y.-C. Microstructure and properties of Cr7C3-CrSi2 composite coatings prepared by plasma spraying. Surf. Coat. Technol. 2021, 412, 127011. [CrossRef]

34. Qi, Z.; Liu, B.; Wu, Z.; Zhu, F.; Wang, Z.; Wu, C. A comparative study of the oxidation behavior of Cr2N and CrN coatings. Thin Solid Films 2013, 544, 515-520. [CrossRef]

35. Lakhtin, Y.M.; Kogan, Y.D. Steel Nitriding; Mashinostroyeniye: Moscow, Russia, 1976.

36. Fossati, A.; Borgioli, F.; Galvanetto, E.; Bacci, T. Glow-discharge nitriding of AISI 316L austenitic stainless steel: Influence of treatment time. Surf. Coat. Technol. 2006, 200, 3511-3517. [CrossRef]

37. Belov, N. State Diagrams of Ternary and Quaternary Systems; MISIS National University of Science and Technology: Moscow, Russia, 2007.

38. Huang, C.-H.; Luo, R.; Zeng, J.; Song, C.-Y. Effect of system parameters on tread-hollow wear of high-speed train wheels. J. Traffic Transp. Eng. 2016, 16, 55-62.

39. Luoma, R. A Thermodynamic Analysis of the System Fe-Cr-Ni-C-O; Acta Polytechnica Scandinavica, Chemical Technology Series; Finnish Academies of Technology: Helsinki, Finland, 2002.

40. Toth, L. Transition Metal. Carbides and Nitrides; Academic Press: New York, NY, USA, 1971.

41. Burkin, V.V.; Tabachenko, A.N.; Afanas'Eva, S.A.; Ishchenko, A.N.; Sammel', A.Y.; Skosyrskii, A.B.; Chupashev, A.V. Synthesis of Two-Layer Metal-Ceramic Materials with High-Velocity-Impact Resistance Based on Refractory Compounds and Titanium. Tech. Phys. Lett. 2018, 44, 344-347. [CrossRef]

42. Młynarczak, A.; Jozwiak, K.; Mesmacque, G. Wear Resistance of Multiphase Diffusion Carbide Coatings. Adv. Eng. Mater. 2003, 5, 789-793. [CrossRef]

43. Zhu, R.; Mi, X. Aging problem and counter method for 1Cr25Ni20Si2 steel nitriding tank. Heat Treat. Met. 2020, 45, 228-230. [CrossRef]

44. Kurny, A.; Mallya, R.; Rao, M. On the formation of austenite during ion nitriding of armco iron. J. Less Common Met. 1988, 144, 201-207. [CrossRef]

45. Kostyk, K.; Hatala, M.; Kostyk, V.; Ivanov, V.; Pavlenko, I.; Duplakova, D. Simulation of Diffusion Processes in Chemical and Thermal Processing of Machine Parts. Processes 2021, 9, 698. [CrossRef]

46. Myshkin, N.K.; Petrokovets, M.I.; Kovalev, A.V. Tribology of polymers: Adhesion, friction, wear, and mass-transfer. Tribol. Int. 2005, 38, 910-921. [CrossRef]

47. Cai, Y.; Zhu, L.; Cui, Y.; Shan, M.; Li, H.; Xin, Y.; Han, J. Fracture and wear mechanisms of FeMnCrNiCo + x(TiC) composite high-entropy alloy cladding layers. Appl. Surf. Sci. 2021, 543, 148794. [CrossRef]

48. Kolesnyk, V.; Peterka, J.; Kuruc, M.; Šimna, V.; Moravčíková, J.; Vopát, T.; Lisovenko, D. Experimental Study of Drilling Temperature, Geometrical Errors and Thermal Expansion of Drill on Hole Accuracy When Drilling CFRP/Ti Alloy Stacks Materials 2020, 13, 3232. [CrossRef] [PubMed]

49. Volosova, M.; Vereschaka, A.; Andreev, N.; Sotova, C.; Bublikov, J. Improvement of the performance properties of cutting tools using the multilayer composite wear-resistant coatings based on nitrides of $\mathrm{Cr}, \mathrm{Mo}, \mathrm{Zr}, \mathrm{Nb}$, and Al. Mater. Today 2021, 38, 1421-1427. [CrossRef]

50. Zaulychny, Y.V.; Hignjak, V.G.; Harchenko, N.A.; Hovorun, T.P.; Hignjak, O.V.; Dolgikh, V.Y. Influence of Interatomic Interaction Processes on the Mechanical Properties of Carbide Coatings Based on Ti, V and Cr, Obtained by Diffusion Metallization. J. Nano Electron. Phys. 2016, 8, 4008. [CrossRef]

51. Kim, Y.S.; Park, H.J.; Lim, K.S.; Hong, S.H.; Kim, K.B. Structural and Mechanical Properties of AlCoCrNi High Entropy Nitride Films: Influence of Process Pressure. Coatings 2019, 10, 10. [CrossRef] 